\title{
Tutejsi i przybysze. Przyczynek do autoetnografii Lanckorony
}

\section{Locals and Visitors. A Contribution to Lanckorona's Autoethnography}

\begin{abstract}
Są takie miejsca, gdzie czas się zatrzymał. No, może nie zatrzymał, ale na pewno bardzo zwolnił. To takie miejsca, o których Marek Grechuta śpiewał, że to „osłona od spiekoty i od deszczu, od tupotu szybkich spraw”. Takim właśnie miejscem jest małe miasteczko, a właściwie większa wieś w Małopolsce, nieopodal Kalwarii Zebrzydowskiej. Lanckorona, bo o niej mowa, to miejsce, z którego nie chce się wyjeżdżać, a spacerując po sennym rynku zabudowanym uroczymi, drewnianymi domkami cofamy się w czasie co najmniej o Ioo lat. I nie przeszkadza nam nawet kilka samochodów zaparkowanych na rynku'.
\end{abstract}

Zacytowany powyżej komentarz podróżnika, który zawitał kiedyś do Lanckorony, jest jednym z wielu podobnych, umieszczanych na portalach internetowych poświęconych turystyce. Zazwyczaj bowiem tę miejscowość opisuje się słowami najwyższego uznania - jako malowniczą, uroczą i magiczną, zaczarowaną, urzekającą, klimatyczną, niezwykłą itd., ale też uśpioną, zaprzeszłą, wyciszoną. Architekt Marek, weekendowy bywalec Lanckorony powiada, że „jest to miejsce, gdzie można się pięknie nudzić” (2012, 6o lat)², z kolei internauta Marcin H. z Krzeszowic, odwiedziwszy w październiku 2017 r. „magiczny rynek”, entuzjastycznie go skomplementowat:

Rynek w Lanckoronie [...] to miejsce niezwykłe. Zaskakująco rozległy, jak na niewielką w końcu miejscowość [...], niezwyczajnie pochyły, otoczony jest niezwykłymi domami [...]. Pod numerem 133 mieści się małe, ale ciekawe

I http://podrozestarszegopana.radom.pl/lanckorona/index.html [dostęp: 29 grudnia 20I9].

2 W nawiasie podaję datę roczną badań oraz inne dane rozmówcy, które nie znalazły się w głównym tekście, np. płeć i wiek, często przybliżony. 
muzeum regionalne. Jest w nim także niewielki sklepik z niebanalnymi pamiątkami. Rynek to nie tylko unikatowa zabudowa. To klimat, widoki na okoliczne doliny [...], a przy dobrej widoczności widać Babią Górę. Czas płynie tu jakoś inaczej; chce się wypić kawę w którejś z kafejek i zjeść do niej domowe ciasto... małomiasteczkowa atmosfera sprzyja zadumie, a dobrze wygląda tu jedynie niespieszny przechodzień. Nic dziwnego, że Lanckoronę upodobali sobie artyści [...]. Chwilo trwaj, miejsce trwaj!3

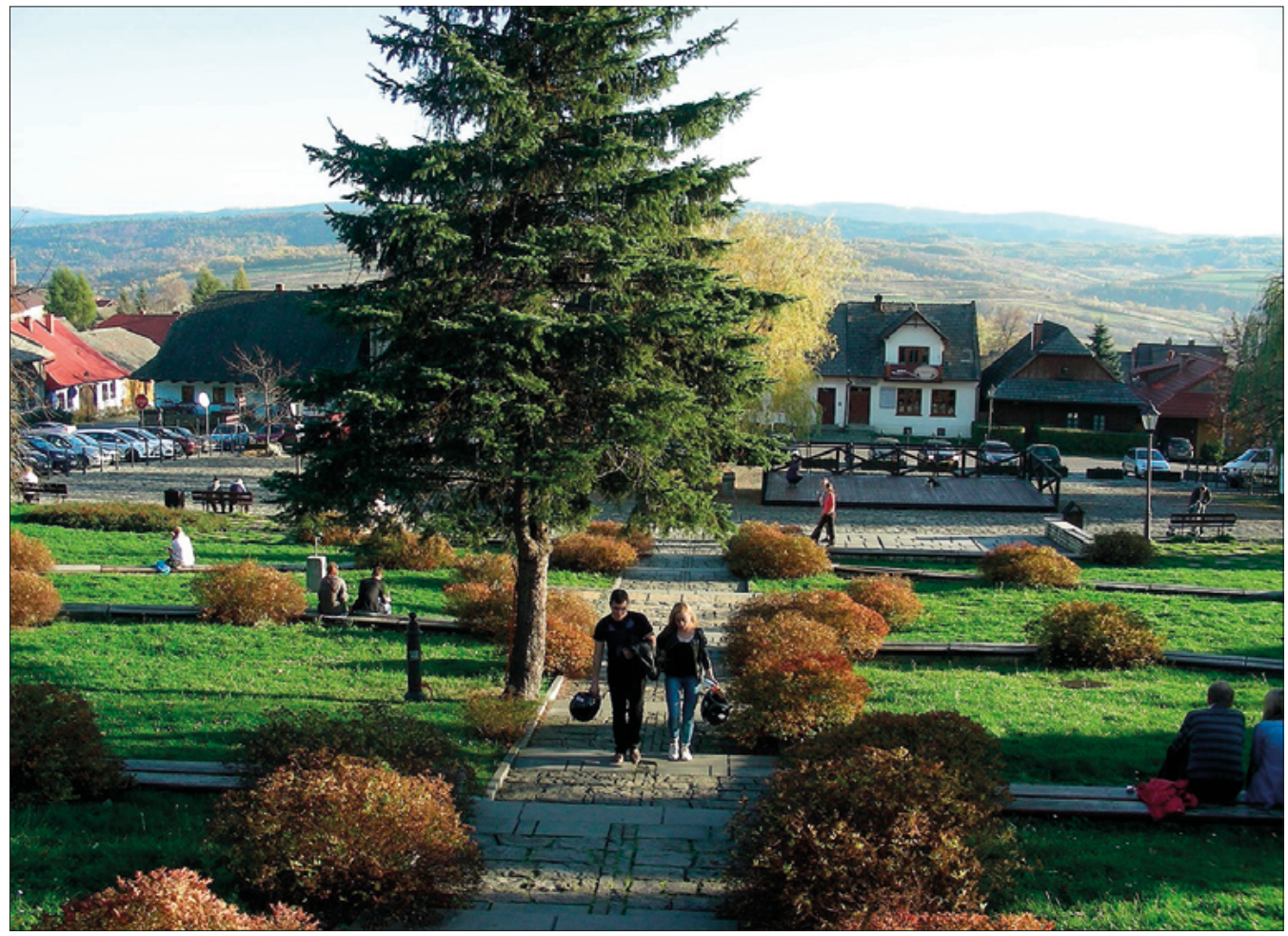

FOT. 1 Lanckorona, widok na rynek (fot. T. Węcławowicz 2014)

Dzieje Lanckorony można przedstawić w zarysie, sygnalizując najważniejsze wydarzenia. Rozpoczyna je nadanie praw miejskich przez Kazimierza Wielkiego w I36r r. W I366 r. król ponowił lokację na prawie magdeburskim i nadał miastu liczne przywileje. Od XIV do XVIII w. było ono siedzibą starostwa niegrodowego. W czasie potopu szwedzkiego zamek na wzgórzu, w którym rezydował starosta, zajęło obce wojsko, a w miasteczku wiele

3 https://pl.tripadvisor.com/ShowUserReviews-g3420966-di3947715-r569952 450-Market_ Square_in_Lanckorona-Lanckorona_Lesser_Poland_Province_Southern_Poland.html [dostęp: 25 stycznia 2020]. 


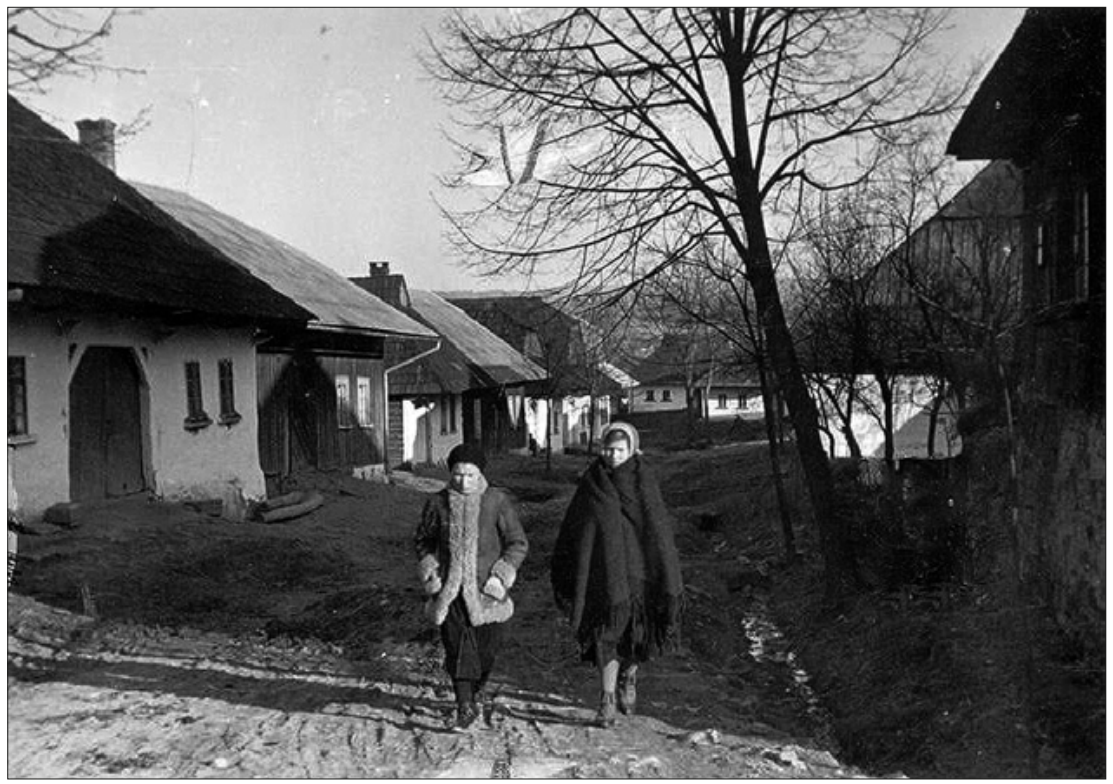

FOT. 2 Lanckorona, ul. Palecka w okresie międzywojennym

(Narodowe Archiwum Cyfrowe, fot. M. Rychlik)

domostw zostało splądrowanych i spalonych. W latach 1770-1772 zamek lanckoroński był jedną z obronnych twierdz konfederatów barskich, wówczas miasto i zamek znacznie podupadty wskutek walk między oddziałami polskimi i rosyjskimi. Po pierwszym rozbiorze starostwo lanckorońskie przypadło Austrii. W 1797 r. cesarz Franciszek II potwierdził dawne przywileje i nadał miastu nowy herb. W I869 r. spłonęła niemal cała drewniana zabudowa rynku, ale w następnych latach miasto zostało odbudowane na dawnym planie. W I934 r. Lanckorona utraciła prawa miejskie, odtąd administracyjnie jest wsią ${ }^{4}$. Mimo to nadal przedstawiana jest jako miasteczko, przede wszystkim w kontekstach reklamy i marketingu.

Niewątpliwie jest jedną z najbardziej rozpoznawalnych i popularnych miejscowości Małopolski. Obecnie przeżywa turystyczny boom, nieporównywalny do wcześniejszych fal popularności w okresie międzywojnia oraz w latach 60. i 70. ubiegłego wieku. Jest on wypadkową tendencji ogólnych, by wymienić najważniejsze: transformację ustrojową po 1989 r., procesy

4 F. Sypowski, Miasta Lanckorony świadki przesztości. Z publicystyki i historii dawnej kultury polskiej kart kilka, Wieliczka 1938; F. Lenczowski, Z dziejów Lanckorony, „Studia Historyczne” 1973, t. 16 (4), s. 569-583; Z. Perzanowski, Lanckorona. Powstanie miasta i dzieje jego rozwoju do końca XVI wieku, [w:] Ojczyzna blizsza i dalsza. Studia historyczne ofiarowane Feliksowi Kirykowi w sześćdziesiątą rocznicę urodzin, red. J. Chrobaczyński, A. Jureczka i M. Śliwa, Kraków 1993, s. I57-I7I. 
globalizacyjne, wprowadzanie programów unijnych. Gwałtownie zmienia się struktura społeczna (starzenie się społeczności lokalnej, odpływ ludzi młodych), struktura zarobkowania (zanik tradycyjnych form gospodarowania, praca większości poza rodzinną miejscowością), a przede wszystkim zmienia się funkcja Lanckorony z rolniczo-rzemieślniczej i letniskowej na rezydencjalno-osiedleńczą i turystyczną5.

Zachodzące tu procesy kulturowe obserwuję na bieżąco, gdyż przyjeżdżam tu od wielu lat. Do ich rozpoznania wybrałam autoetnograficzną perspektywę ${ }^{6}$ jako najbardziej adekwatną do mojej sytuacji badawczej - etnologa mającego osobiste związki z analizowaną rzeczywistością społeczno-kulturową. Zastosowanie tej strategii pozwala na konfrontację własnego doświadczenia z doświadczeniami innych uczestników określonej kultury. Daje też większe możliwości zrozumienia miejscowej kultury i występujących w niej relacji społeczno-kulturowych, praktyk, wyobrażeń, przeżyć. Zwieńczeniem moich etnograficznych penetracji będzie opisująca analiza lanckorońskiego świata przeżywanego, zapamiętanego i obecnie doświadczanego, a niniejszy tekst jest skromnym jej zaczątkiem. Warstwą empiryczną są wypowiedzi pozyskane różnymi technikami: wywiadu kwestionariuszowego ${ }^{7}$, wywiadu swobodnego, nieformalnych rozmów przy okazji uczestniczenia w codzienności i w różnych okolicznościowych wydarzeniach ${ }^{8}$. W artykule wykorzystuję ich niewielką część, głównie z ostatnich dziewięciu lat, sporadycznie sięgam do wcześniejszych. Uzupełniają je głosy internautów $\mathrm{z}$ forów tematycznych poświęconych podróżowaniu i turystyce, jak też z nielicznej literatury wspomnieniowej. Na początek kilka spostrzeżeń - tylko pozornie niepowiązanych - z mojej etnograficznej pracy terenowej w lipcu ubiegłego roku.

Notatka pierwsza. Upalnym, późnym popołudniem z mężem i wnukiem wracamy do hotelu ze spaceru po uliczkach. Zwabieni zapachem pieczonego chleba wstępujemy do miejscowej piekarni, ale na chleb trzeba jeszcze poczekać, dopiero jest w piecu. W koszu widzę bułki, takie same, po które dawno temu posyłała mnie babcia, rodowita lanckoronianka. Pytam, kiedy były upieczone. „Są z rana” - mówi sprzedawczyni. „A kiedy będą

5 Por. Strategia rozwoju gminy Iggg-2015, Strategia rozwoju spoteczno-gospodarczego 2012-2020; oba dokumenty pozyskano ze strony internetowej Urzędu Gminy Lanckorona: https://bip. malopolska.pl/uglanckorona,m,233013,dokumenty.html [dostęp: 25 stycznia 2020].

6 Autoetnografia-technika, metoda, nowy paradygmat? O metodologicznym statusie autoetnografi, red. A. Kacperczyk, „Przegląd Socjologii Jakościowej” 2014, nr 3.

7 Metodą wywiadu kwestionariuszowego były prowadzone badania w latach 70. i 80. xxw.

8 O zasadności i specyfice nieformalnych badań etnograficznych ostatnio szeroko wypowiedział się T. Buliński, Informator, rozmówca, wspólnik. Obrazy relacji Antropologa z Innym, „Zeszyty Naukowe Uniwersytetu Jagiellońskiego. Prace Etnograficzne” 2019, z. I, s. I-16. 
świeże?" - dopytuję. Ona, wyraźnie zniecierpliwiona odpowiada, że pieczywo sprzedaje się w godzinach otwarcia, a informacja wisi na drzwiach. Następnego dnia ponownie idziemy do piekarni. Spotykam tam mego stryja, też tutejszego, witamy się serdecznie. Wnuk ma ochotę na słodką drożdżówkę, proszę o jedną. Ta sama pani sprzedawczyni z uśmiechem podaje mu placek i nie przyjmuje zapłaty, tłumacząc: „Drożdżówka niedzisiejsza, wczoraj pieczona. Proszę przyjść późno wieczorem, będą świeże. Tak po ósmej”.

Notatka druga. Poszliśmy na pizzę do restauracji, która od jakiegoś czasu zwie się Verona, wcześniej była to po prostu Sielanka i wtedy należała do spółdzielni Społem. Dziś jest w prywatnych rękach. Mieści się w tym samym miejscu, w tym samym budynku z przełomu lat 60 . i 70 . ubiegłego wieku, układ pomieszczeń też niezmieniony, tylko wnętrze i umeblowanie odświeżone. W karcie dań trochę z kuchni polskiej, trochę ze śródziemnomorskiej, ale najwięcej pizzy. Smacznie i drogo. W oczekiwaniu na lanckorońską zupę i włoską pizzę (to nazwy potraw w menu) opowiadam o swoich letnich wakacjach i dancingach w starej Sielance, na których bawiłam się w gronie sezonowo zjeżdżającej młodzieży. Naszej rozmowie przysłuchuje się siedząca przy sąsiednim stoliku para, on mniej więcej w moim wieku, ona trochę młodsza. Mężczyzna włącza się do moich wspomnień, Lanckoronę zna tak jak ja, od piątego roku życia przyjeżdżał tu do wuja „Za górę" - to północny stok, zasiedlony znacznie później niż część południowa z czworobocznym rynkiem. Na co dzień mieszkają w Tarnowie, ale choć raz w roku - jak mówi: „Muszę tu przyjechać, by odświeżyć pamięć. Ciągnie mnie atmosfera Lanckorony, ale dawnej, bez tego hałasu, bez tego tłumu turystów zalewających rynek w soboty i w niedziele. Przyjeżdżam w tygodniu, uciekam w weekend”. Lanckoronę „musiał pokazać swojej kobiecie, jak tylko ją poznał”. Ona jest zauroczona: „Gdy pierwszy raz tu przyjechałam, to wszystko fotografowałam, nie mogłam się powstrzymać”. Od tamtej pory razem tu wpadają.

Notatka trzecia. Niedzielne południe, omijamy rynek zastawiony parkującymi samochodami i idziemy na tzw. „Zamek”, czyli lanckorońską górę porośniętą lasem, na szczycie której zachowały się ruiny średniowiecznego zamku. Teren objęty jest ochroną UNESCO. Natykamy się na grupki turystów zmierzających tam gdzie my. Dogania nas samochód, w środku rodzina z małym dzieckiem, kierowca pyta, ,jak dojechać na ruiny”. Na skraju lasu polana, gdzie parkuje kilka aut, z oddali dobiegają pokrzykiwania, śmiech, warkot motocykla. Umykamy w najbliższą uliczkę, niestety też zastawioną autami. Na poboczu, przed otwartą furtką do ogródka jednego z domów głośno rozmawiają dwaj mężczyźni. Z rozmowy wynika, że są sąsiadami, przyjechali na weekend. Są zniesmaczeni weekendowym 
najazdem turystów, słyszę: „Coraz trudniej to wytrzymać”. Z oburzeniem wypowiadają się o jakimś spotkaniu, na którym nie spełniono ich postulatu zakazu parkowania w rynku.

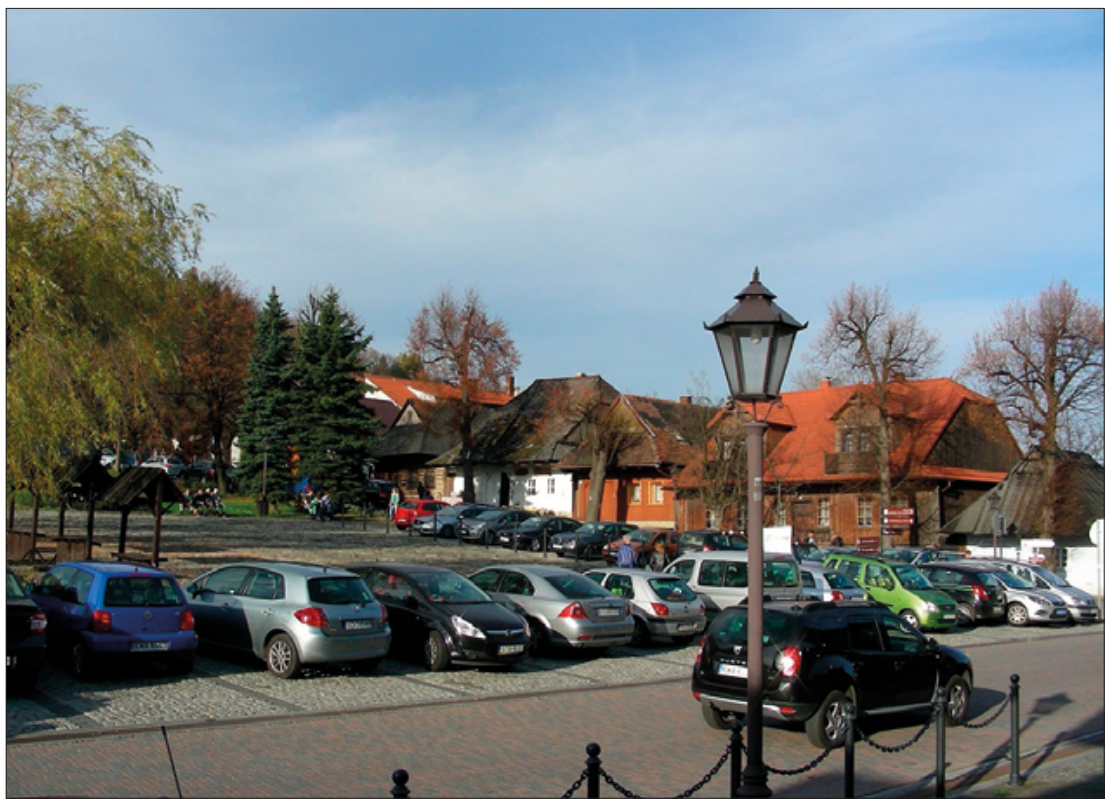

FOT. 3 Lanckorona, weekendowy parking na rynku (fot. T. Węcławowicz 20I4)

Trzy etnograficzne zapiski sygnalizują różnice w doświadczaniu lokalnej przestrzeni, zarówno w jej wymiarze materialnym czy fizycznym, jak i symbolicznym. Ich konsekwencją są napięcia, które szczególnie ujawniają się w relacji „prawdziwi lanckoronianie” a „przybysze”. To rozróżnienie pożyczyłam od jednej z moich rozmówczyń, rodowitej lanckoronianki (20I8, 63 lata). „Prawdziwi” to inaczej tutejsi, trwale zasiedziali w miejscowości, choć niekoniecznie w niej urodzeni. Wśród „przybyszy” większościową grupę tworzą czasowi rezydenci, którzy posiadają tutaj domy, lecz na stałe mieszkają gdzie indziej, a Lanckoronę odwiedzają wahadłowo. Przybyszami są też nowi mieszkańcy, którzy zdecydowali się tu osiąść na stałe. Osobną kategorią są turyści przyjeżdżający okazjonalnie i masowo.

Tylko na pierwszy rzut oka podział jest klarowny, wpisujący się w opozycję swój - obcy. Natomiast komplikuje się, jeśli zastanowić się nad różnymi formami bycia w przestrzeni i jej przeżywania, bo tak rozumiem doświadczenie przestrzeni przez człowieka. Sformułowanie to stosuję ze świadomością jego wieloznaczności, różnych sposobów definiowania, interpretacyjnych 
możliwości, ale też i ograniczeń, bo - jak pisał kiedyś, zapewne przewrotnie, Clifford Geertz - „czymkolwiek jest antropologia doświadczenia, jedno przynajmniej jest jasne - jest tak obfita, wielokształtna i w pewnym stopniu tak tworzona od ręki jak samo doświadczenie. Gdziekolwiek się znajdujemy, nie jest to na pewno miejsce u wrót do królestwa paradygmatu”. Termin „doświadczenie" objaśnił krótko jako odczuwanie życia, jego przeżywanie ${ }^{\mathrm{r}}$. Zmierzając do uściślenia trudno uchwytnego pojęcia, podążam tropem Hanny Buczyńskiej-Garewicz i fenomenologicznego rozumienia przestrzeni, które:

kształtuje się dopiero na gruncie relacyjnego jej rozumienia, dotyczy konstytuowania przestrzeni poprzez ludzki sposób bycia. Ta szczególność konstytutywnego dla przestrzeni sposobu istnienia człowieka zwie się zamieszkiwaniem. [...] To swoista harmonia wytwarzana między człowiekiem a jego otoczeniem, która ma charakter przede wszystkim duchowy, gdyż realizuje się w akcie rozumienia miejsca, w jakim człowiek się znajduje. [...] Przestrzeń wytwarza się pierwotnie w doznaniach, przeżyciach, nastrojach, działaniach. Jej źródłem jest doświadczenie życia, dzięki któremu zostaje ukonstytuowana. [...] Relacyjność pojęcia przestrzeni jest więc [...] realizowana przez odwołanie się do przeżyć podmiotowych, w jakich przestrzeń doświadczona pojawia się․

Autoetnograficzny paradygmat badawczy obliguje do refleksji nad własnym doświadczeniem w relacji do badanej rzeczywistości. Zatem zastanawiam się nad swoim „byciem” w lanckorońskiej przestrzeni. Nie urodziłam się tutaj, ale z Lanckoroną jestem związana rodzinnie, w dzieciństwie spędzałam u babci wakacje, od wielu lat przyjeżdżam kilka razy w ciągu roku. Nie mam tu własnego domu, zwykle gościli mnie krewni, od jakiegoś czasu mieszkam w hotelu. W jakiejś części czuję się tutejsza, jestem też przybyszem, bywam turystką. Nigdy nie zapytałam, jak postrzegają mnie mieszkańcy, lecz zdarzenie w piekarni pokazuje, jak ważna jest miejscowa relacja rodzinna, by choć częściowo została przełamana bariera obcości. Porównuję się do mojego rozmówcy z restauracji Verona. Mamy wiele wspólnego, łączy nas emocjonalny, nostalgiczny i refleksyjny stosunek do przestrzeni Lanckorony. Doświadczamy jej podobnie, odwołując się do podmiotowych, jak mówi H. Buczyńska-Garewicz, czyli naszych własnych przeżyć. Oboje odczuwamy dysonans pomiędzy dawną a dzisiejszą

9 C. Geertz, Zdobywając doświadczenia, autoryzując siebie, [w:] Antropologia doświadczenia. Z epilogiem Clifforda Geertza, red. V.T. Turner, E.M. Bruner, Kraków 2011 , s. 395-396.

Io Tamże, s. 395 .

I I H. Buczyńska-Garewicz, Miejsca, strony, okolice. Przyczynek do fenomenologii przestrzeni, Kraków 2006, s. I0, I3, I4. 
Lanckoroną. On przywołał beztroskie wakacje w cichym, kameralnym otoczeniu, kąpiele w basenie. Po części są to i moje doświadczenia, w basenie także się pławiłam, niemniej jednak nakładają się na nie obrazy Lanckorony z kocimi tbami na drogach, z drabiniastymi wozami załadowanymi trawą bądź sianem, babcią prowadzącą sklep czy dziadkiem kilka razy dziennie przynoszącym w wiadrach wodę ze studni w rynku. Odgłosy sieczkarni, młockarni, charakterystyczne wiejskie zapachy. Pamiętam Lanckoronę tętniącą życiem, wypełnioną pracowitą codziennością zakorzenionej tu społeczności rolniczo-rzemieślniczej. Lanckoronianin Stanisław Kawa zapytany, czy jako dziecko bawił się z dziećmi przyjezdnymi, odpowiedział:

No ja się tam specjalnie nie bawiłem. [...] Kiedyś to cięższa robota była w polu, wiadomo, kiedyś się snopki stawiało, kosą kosiło. Jak mój tata kosił kosą, to dosłownie tydzień kosił pszenicę, tydzień owies, tydzień żyto i to trzeba było zwozić, układać w stodole, później na maszynę. To była monotonia na tym gospodarstwie i ciężko było. Zostali już, jak to mówią, niedobitki. Zawzięci na to pole. Koni zostało pięć czy sześć w Lanckoronie ${ }^{12}$.

Moje usytuowanie było nieco inne. Przypominam sobie bliskie relacje z tutejszymi koleżankami, gdy przyjeżdżałam na dwa miesiące wakacji, ale nierzadkie były chwile, gdy one musiały pomagać w gospodarstwie, a ja spędzałam czas pośród nastolatków jak ja przybyłych na letnisko. Później, gdy już nie co roku tu bawiłam, kontakty ustały.

Dziś jestem świadoma ówczesnego dysonansu między tradycyjnym stylem życia miejscowych a nowoczesnym - letników, który ujawnił się wraz z napływem turystów w latach 60. i 70. Xx w. Już wówczas rysował się rozdział między tutejszymi a przyjezdnymi, ale w odróżnieniu od obecnego tamten miał cykliczny charakter - wygasał z końcem wakacji i pojawiał się z początkiem następnych. Natomiast w ówczesnym zderzeniu wartości i w kontekście trudnego czasu epoki PRL-u wyobrażeniowo funkcjonowała dawna Lanckorona jako miejska wspólnota idealna, mityzowane odniesienie do zgrzebnego, skromnego i skomplikowanego "tu i teraz”. Niejednokrotnie słuchałam opowieści przywołujących idylliczny obraz przedwojennego świata, zgodnego współżycia mieszkańców, ich działalności na rzecz wspólnego dobra. Rozmówcy wspominali też przyjazną koegzystencję z przybyszami z zewnątrz: właścicielami bądź rezydentami

I2 K. Wiśniak, Powietrznicy w Lanckoronie. Historia letniska, Kraków 2008, s. 42. 
powstałych wtedy kilku willi i pensjonatów, także z letnikamir ${ }^{\text {r3 }}$. Na przykład moja rodzinna tradycja przechowała pamięć o oddaniu przez pradziadka, wówczas burmistrza, części prywatnego ogrodu w celu przebicia gminnej drogi. Babcia opowiadała o serdecznej przyjaźni z jedną z córek gospodarza willi Słonecznej, od jego nazwiska potocznie zwanej „U Polaczków”.

Wartościowanie przeszłości zawsze ma charakter kontekstowy i w zależności od sytuacji jest wypełniane różnymi treściami ${ }^{14}$. Współczesna moda na Lanckoronę też wywołuje podobne reakcje, ale tym razem mityzowana jest wiejska przeszłość powojenna. Najpierw oddaję głos mieszkańcom, zasiedziałym w Lanckoronie od wielu lat:

Dawna Lanckorona była wesoła, ludzie się znali, tu poszli, tam poszli, zagadali. A teraz wszyscy siedzą po domach, pracują, a to w Krakowie, Wadowicach, w Suchy. Jak wrócą, to do domu, bo mało czasu. A w niedzielę to by poszli na rynek, a tam się nie da, pełno turystów i samochodów. Tyle co do kościoła się pójdzie, to tam się czasem kogoś spotka i porozmawia (20I2, mężczyzna, ok. 75 lat).

Przedtem było inaczej. Uchowało się świnkę, miałem swoje mleko, jajeczko kura zniosła. Dziśs nikt w polu nie robi, bo się nie opłaca. Opłaca się nie robić i za to dają pieniądze. Jak na polu orałem, to pozdrowili: „Niech będzie pochwalony!” i należało podziękować: „Bóg zapłać”. A dziś? Tyle tu ludzi nowych, naszych coraz mniej, pomarli, uciekli do miasta (2015, mężczyzna, 53 lata).

Idealizowany obraz przeszłej harmonijnej wspólnoty był wielokrotnie przywołany przez mych rozmówców. Uciążliwości minionego systemu „realnego socjalizmu" zeszły na daleki plan; wspominano je wtedy, gdy wprost o to zapytałam, ale i tak były uważane za nieważne. Wyobrażeniowa wspólnotowość ujawniła się na wielu płaszczyznach doświadczania przestrzeni: w codziennym bytowaniu, w sferze religijnej, świątecznej, ludycznej, w tutejszych relacjach społecznych.

Tendencję do mityzacji Lanckorony wykazują też przybysze, lecz uwypuklają inne wartości. Sielskiego obrazu, ciszy i spokoju szuka mój przygodny rozmówca z Verony, przyjeżdżając w tygodniu i uciekając w weekend. Bogdan Frymorgen, pracujący w Londynie dziennikarz, autor wysmakowanego artystycznie albumu fotograficznego pt. Lanckorona, umieścił

13 Badania z drugiej połowy lat 70. Xxw.

I4 R. Godula-Węcławowicz, Miasteczko Lanckorona. Mityzacja przesztości, [w:] Evropské město. Identita, symbol, mýtus, red. B. Soukupová, H. Novotná, Z. Jurková, A. Stawarz, Bratysława 2010, s. 167-173. 
w nim dedykację dla swojej lanckorońskiej prababki, Wiktorii Tondyry. Uważa bowiem, że:

Pamięć jest genetyczna. Gdy przyjeżdżam do Lanckorony czuję, że tu się zacząłem. [...] Dziś na rynek nie wjeżdżają już drabiniaste wozy, a po jego bruku galopują wyłącznie mechaniczne konie. Weekendy w Lanckoronie to regionalne Champs-Élysées, prawdziwa inwazja uciekających z miasta ludzi. W tygodniu powraca spokój. Wtedy najchętniej fotografuję tę wioskę, starając się jej nie spłoszyć. Patrzę na nią w czasie przeszłym, ale podziwiam w teraźniejszym5.

Jak widać z przytoczonych przykładów, relacyjny stosunek do Lanckorony mają zarówno tutejsi, jak i przybysze. Odwołują się do przeżyć podmiotowych, naznaczonych silną więzią z lanckorońską przestrzenią - tyle że zgoła inaczej. Mityzacja przeszłości, jak i współczesne doświadczenia ujawniają nieprzystawalność światów obu grup. Zderzenie odmiennych stylów życia i systemów wartości powoduje pojawienie się napięć o podłożu kulturowym. Renata van der Logt, nowa właścicielka przedwojennej willi, w której sezonowo uruchamia kawiarnię, tak zdiagnozowała swoje zamieszkanie w Lanckoronie: „Jest to bardzo, myślę, odizolowana społeczność, która ma swój własny język, własny rytm i w ogóle cały wszechświat. [...] Oni znają się bardzo dobrze. Ktoś, kto nagle w wieku lat czterdziestu się tu przeprowadza, już nigdy tego nie przeskoczy"16.

Z kolei autorka owego, zapożyczonego przeze mnie, rozróżnienia mówi: „Przybysze chcą nas ustawiać, dla lanckoronian już nie ma miejsca. A najgorsi są ci, co z Lanckorony wyjechali, trochę powąchali miasta, a teraz chcą tu rządzić” (2018, 63 lata). Napięcia dobrze obrazuje wielokrotne przywoływanie przez autochtonów pewnego zdarzenia, które ma cechy wędrującej opowieści. Miejscowi chłopcy wybrali się do nowo otwartej kawiarni, "poszli zobaczyć, jak tam jest, chcieli napić się piwa, ale im nie sprzedali, powiedzieli, że tu nie dla nich. No, nie obsłużyli ich" (201 I, mężczyzna, 35 lat) ${ }^{17}$. Zresztą kawiarnie, których w ostatnich latach powstało kilka, na ogół postrzegane są jako miejsce dla przybyszy i turystów: „Są za drogie, tam piwo po Io zł, za to w sklepie kupi trzy piwa. No to co to za rachunek, to się nie opłaci. Lepiej w domu się napić, a jak się chce z kim pogadać, to w domu nie w kawiarni” (2017, mężczyzna, ok. so lat).

I5 B. Frymorgen, Lanckorona, Londyn 2015 , s. 4.

I6 K. Wiśniak, dz. cyt., s. 56.

17 Data dotyczy czasu zanotowania tylko tej wypowiedzi, jak wcześniej zaznaczyłam, opowieści wysłuchałam kilka razy i w różnych latach. 


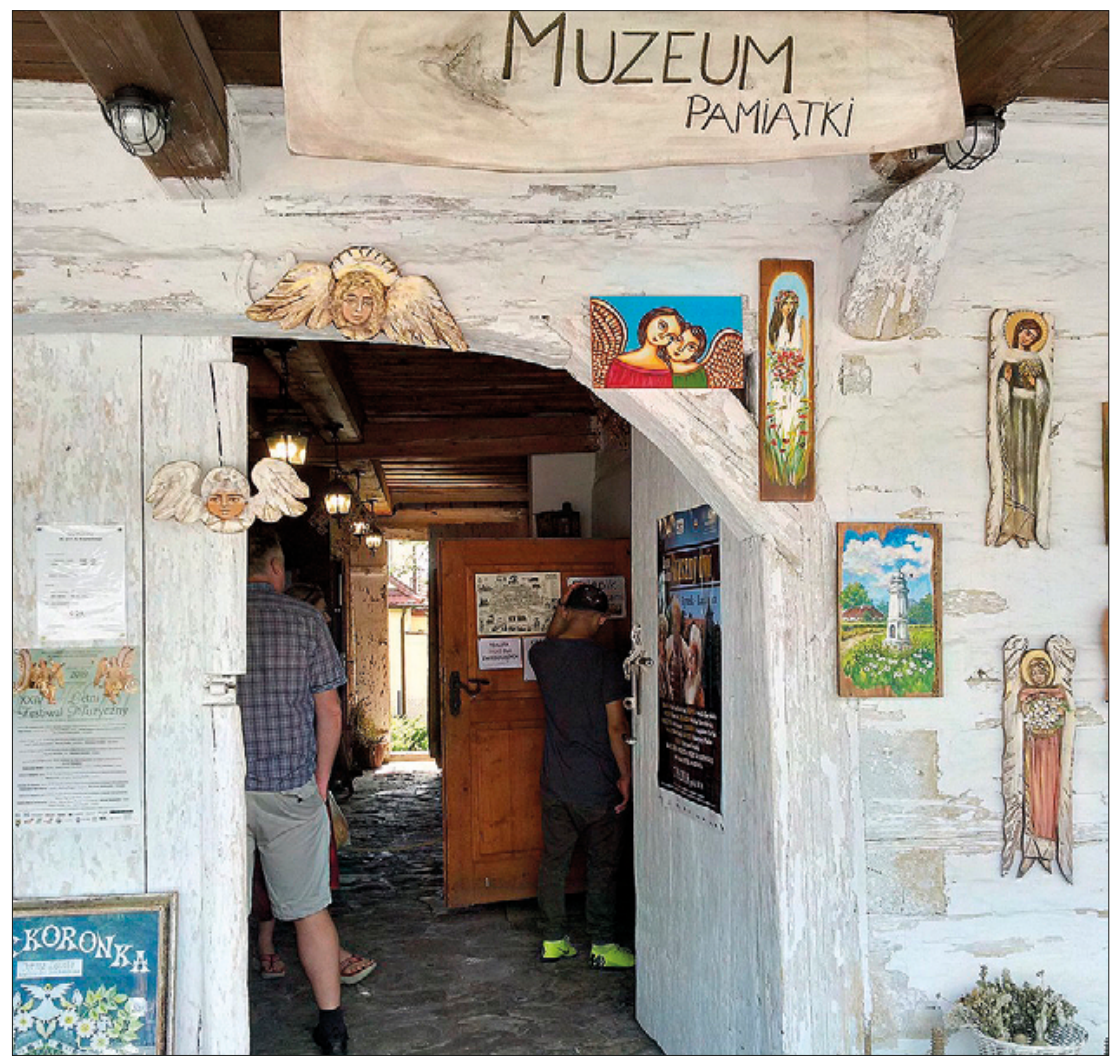

FOT. 4 Lanckorona, lokalne muzeum (fot. T. Węcławowicz 2019)

Zagadnęłam o to Kasię i Marka z pokolenia trzydziestolatków. Oboje od urodzenia mieszkają w Lanckoronie w wielopokoleniowych rodzinach, wykształcenie zdobyli na uczelniach w Krakowie, pracują w mieście i codziennie tam dojeżdżają. Kasia nie dowierza owej opowieści i bez oporów bywa we wzmiankowanej kawiarni, nawet bardzo ją lubi (2019, 33 lata). Marek wie o zdarzeniu, lanckorońskich kawiarni unika, woli „pojechać do Krakowa na Kazimierz, gdyż tam jest ciekawiej” (2019, 30 lat). Zastanawiam się, czy to wyłącznie pokoleniowa różnica, czy też odmienność doświadczeń życiowych w porównaniu do rodziców i dziadków, prowadząca do redefinicji tradycyjnych wartości i zachowań ${ }^{18}$.

Rozmowa toczyła się w kilkuosobowym gronie, zróżnicowanym wiekowo. Przypomniałam inną, dawną lanckorońską kawiarnię, a właściwie klubo-

I8 T. Warczok, Globalizacja i konsumeryzm. O konsumpcji jako strategii zaradczej wobec traumatogennych zjawisk globalizacji, [w:] Konsumpcja - istotny wymiar globalizacji kulturowej, red. A. Jawłowska, M. Kempny, Warszawa 2005, s. 259. 
-kawiarnię, w której spędzałam wieczory przy kawie i telewizorze w gronie wakacyjnej i zaprzyjaźnionej z nami miejscowej młodzieży (to moje czasy licealne). Kawiarnia mieściła się w domu przy rynku, niedługo potem powstała tam izba regionalna z inicjatywy dr Hanny Pieńkowskiej, krakowskiego konserwatora zabytków, i Antoniego Krajewskiego, nauczyciela z Krakowa, entuzjasty Lanckorony i współzałożyciela Towarzystwa Przyjaciół Lanckorony. W zbiórce eksponatów pomogli pracownicy i studenci Katedry Etnografii Słowian Uniwersytetu Jagiellońskiego w ramach wakacyjnych praktyk etnograficznych ${ }^{\text {19. }}$. Izba istnieje do dziś, potocznie nazywana jest "muzeum”.

Wracając do wspomnień - w owej kawiarni czekaliśmy na babeczki z kremem poziomkowym i truskawkowym, świeże, pachnące, chrupiące. $\mathrm{Z}$ nostalgicznej i smakowitej wycieczki w przeszłość wyrwała nas trzeźwa uwaga jednego z uczestników spotkania, że to była świetlica, a nie kawiarnia, działająca przez cały rok, zorganizowana społecznie przez samych lanckoronian, głównie przez spółdzielnię szewców. Przychodzili tam mieszkańcy popatrzeć na telewizję, gdyż tylko nieliczni mieli własny odbiornik. $\mathrm{Z}$ naciskiem zaznaczył, że letnicy zjawiali się tylko w lecie. I tak podsumowal tę rozmowę:

Dziś już Lanckorona nie jest nasza. Nie podoba mi się ta Lanckorona, w soboty i w niedziele nie wyjdziesz na rynek, bo pełno samochodów i kramy. Auta stoją wszędzie, pod naszymi oknami na chodniku. Śmiecą, taki wyrzuci śmieci pod samochód i pojedzie, a śmieci zostawi. Do naszego ogrodu wrzucają butelki po piwie, puszki. E, szkoda gadać (2019, mężczyzna, ponad 80 lat).

Podobne niezadowolenie z weekendowego „najazdu” wykazali dwaj rezydenci przywołani wyżej w trzeciej notatce.

Zastanawia mnie zbieżność w postrzeganiu turystów przez mieszkańców, tych rodowitych i przybyszy. Przeszkadzają, zakłócają ich własne, lanckorońskie terytorium. Na tej płaszczyźnie obie grupy formułują podobne roszczenia wobec przestrzeni, która powinna stwarzać możliwość relaksu, spokojnego spędzenia niedzieli, wyjścia na rynek, spaceru do lasu. Natomiast wątpię, by zbieżność oczekiwań była tożsama z percepcją przestrzeni jako wspólnego dobra. Uświadamiam sobie, że pośród autochtonów i przybyszy są właściciele sklepów, kawiarni, pensjonatów, lodziarni,

I9 J. Bujak, Jak się zaktada muzeum, „Przekrój” 1967, nr I183, s. 4-5; tenże, Problem szkolenia studentów etnografii w zakresie muzealnictwa etnograficznego, „Rocznik Muzeum Etnograficznego w Krakowie” 1968, R. 3, s. 267-272; R. Kantor, Muzeum w Lanckoronie w świadomości i ocenie mieszkańców, „Zeszyty Naukowe Uniwersytetu Jagiellońskiego. Prace Etnograficzne” I981, z. I4, s. 59-68. 


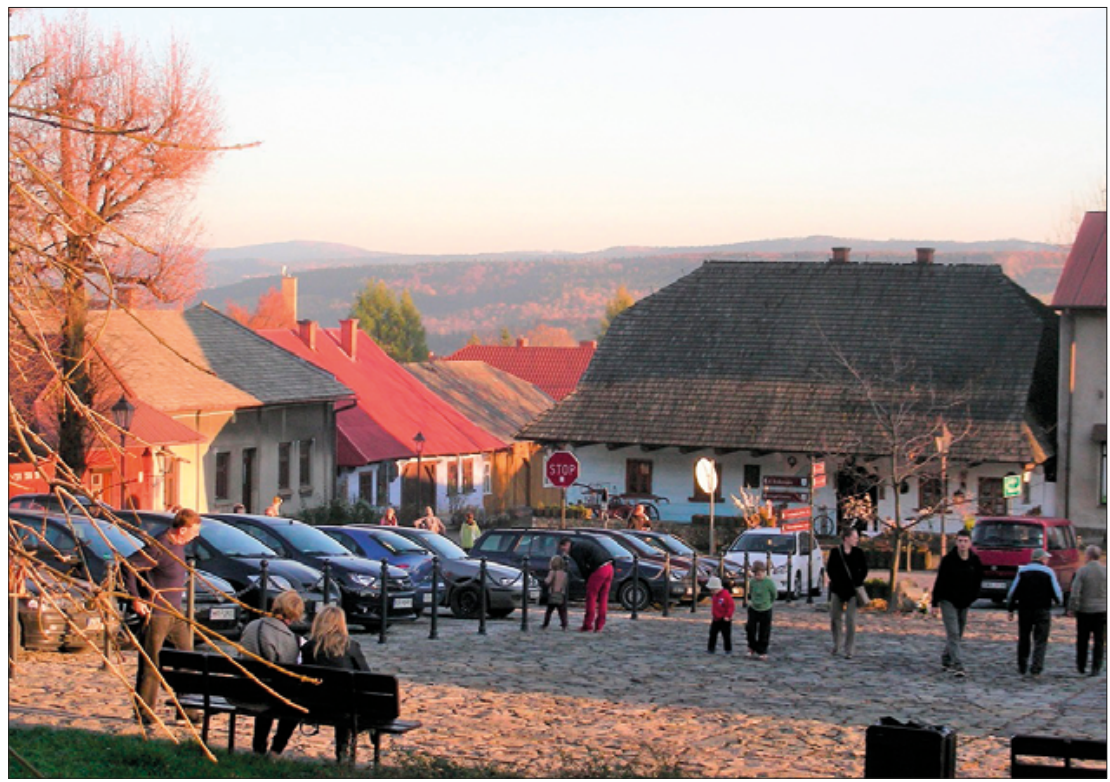

FOT. 5 Lanckorona, weekendowy najazd turystów (fot. T. Węcławowicz 2013).

restauracji. Czy oni podobnie przeżywają boom turystyczny? Trudno mi sobie wyobrazić, by negowali korzyści stąd płynące.

Do tematu powróciłam przy okazji grudniowego wydarzenia „Anioł w miasteczku”. Odbywa się od kilkunastu lat i jak inne cykliczne festiwale: Jarmark Wielkanocny, Jarmark Świętojański, Romantyczna Lanckorona, Terra Artis, pomyślany był, by wypromować „urokliwe miasteczko na lanckorońskim wzgórzu”. Festiwal obserwuję niemal od chwili, odkąd się pojawił, choć nie co roku - w zeszłym pojechałam po kilku latach nieobecności. Zaskoczył mnie rozmach imprezy, od skromnego spotkania lokalnych entuzjastów przerodziła się w festiwal z licznymi towarzyszącymi wystawami, warsztatami plastycznymi, koncertami, wykładami, konkursami, wjazdem Mikołaja na koniu, chodzeniem po domach z życzeniami. Służy nie tylko promocji, rozrywce i sprzedaży wyrobów lokalnych, od jakiegoś czasu organizowana jest kwesta na cel dobroczynny i społeczny, w 2019 r. zbierano datki na leczenie dla dwóch dziewczynek publicznie przedstawionych imieniem i nazwiskiem. Wielu uczestników przebranych było za anioły, nieliczni za diabły, pośród aniołów wyróżniała się grupa emerytów z Krakowa z osiedlowego domu kultury. Mieszkali w tym samym hotelu co ja, miałam więc okazję z nimi porozmawiać. Przyjechali „miło spędzić czas, bo mają go w nadmiarze”. Pochwalili wyśmienite pierogi i dobrą zabawę, charytatywny aspekt umknął ich uwadze. Zmierzając do rynku, na krzakach wzdłuż drogi dostrzegłam 
zawieszki z postacią anioła reklamujące imprezę i zarazem wyznaczające kierunek. Wokół rynku rozłożyły się kramy z miodami, konfiturami, ciastem, chlebem, nalewkami, artystyczną ceramiką i szkłem, tkaninami, starociami i czym tam jeszcze. Na scenie pod namiotem odbywała się taneczna zabawa dla dzieci, Koło Gospodyń z Jastrzębi ${ }^{20}$ oferowało barszcz i kiełbaski z grilla, od stoiska Stowarzyszenia Lanckoronianek rozchodził się zapach lanckorońskiej zupy, a mnie nurtowała myśl o recepcję festiwalu. Od Lanckoronianek dowiedziałam się, że wśród uczestników nie było nikogo z miejscowych oprócz członkiń obu stowarzyszeń i dzieci z podstawowej szkoły, które kolorowały książeczki na rzecz niepełnosprawnych dziewczynek. Zagadnęłam samotnego, starszego mężczyznę, stojącego pod podcieniami, od którego usłyszałam: „No na co to? Stare baby przebrane za anioły, to głupie! Żeby jeszcze dzieci, proszę bardzo, ale starzy? Sami obcy, to nie dla nas". Na moją replikę - „A jednak Pan tu jest” - nieco zaskoczony odpowiedział: „Bom przyszed popatrzeć, tak z ciekawości”. A po chwili: „No jeszcze z Jastrzębi przyjdzie jakaś szkoła, ale w tym roku ich nie było".

Zdaniem Ewy, nauczycielki, pięćdziesięciolatki od urodzenia żyjącej w Lanckoronie, festiwal ma dobre i złe strony. Cel jest szlachetny, podoba

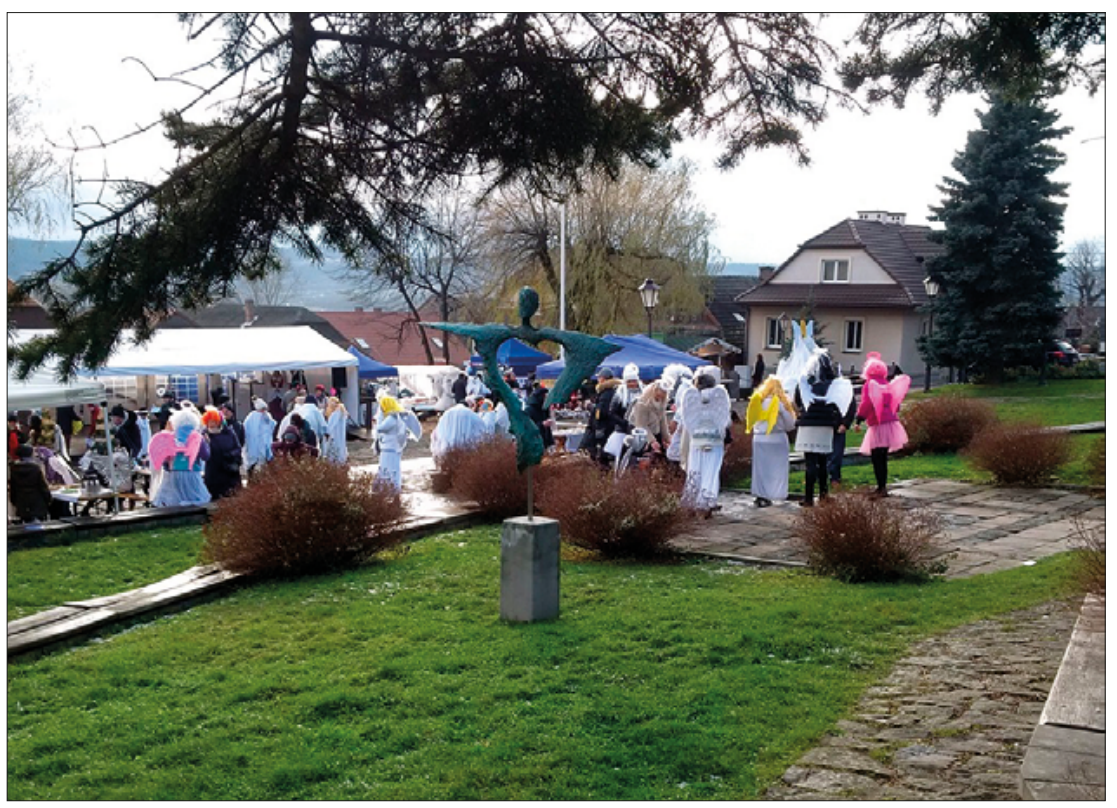

FOт. 6 Lanckorona, grudniowy festiwal „Anioł w miasteczku”

(fot. T. Węcławowicz 2019)

20 Jastrzębia, dawne przedmieście miasta Lanckorony, dziś odrębna wieś. 
jej się zwyczaj chodzenia z życzeniami przez dzieci od domu do domu. Chodzą dzieciaki z Lanckorony i obce. Zawsze jest przygotowana, ma czekoladę, cukierki. Natomiast przeszkadza jej hałas, ciżba kłębiąca się na rynku i nieporządek, jaki zostawiają po sobie turyści. Drążąc temat, zwracam uwagę, że przecież dzięki temu zarabiają kawiarnie, restauracja, pensjonaty, sklepy. W odpowiedzi słyszę, że nie jest to najważniejsze, ponadto dotyczy niewielkiej liczby osób, a handlowy pożytek rozkłada się nierówno, bowiem właścicielami większości firm są przyjezdni, czyli nierodowici lanckoronianie (2019). To opinia wyważona, jedna z niewielu, gdyż rezerwa wobec projektów podejmowanych przez aktywnych działaczy jest faktem: „Te imprezy nie są dla nas. Te dżezy - kogo to interesuje?” (2019, kobieta, ok. 50 lat), „Lanckorona nie ma z tego nic” (2019, mężczyzna, 43 lata).

O postrzeganie nowych przedsięwzięć pytam Katarzynę, członkinię Rady Gminy. Pochodzi z Sułkowic, sąsiedniego miasteczka, ale od zamążpójścia kilkanaście lat temu mieszka w Lanckoronie. Dobrze orientuje się w sprawach gminy, wie też wiele o nastrojach społecznych, gdyż jako położna ma bezpośredni kontakt z mieszkańcami, odwiedzając młode matki $\mathrm{w}$ ich domach. Widzi różnicę między społecznością sułkowicką a lanckorońską: „Tam inaczej niż w Lanckoronie, kobiety robiły coś wspólnie, działało Koło Gospodyń Wiejskich, w Lanckoronie nic takiego nie było”. $\mathrm{Z}$ jej inicjatywy powstało Stowarzyszenie Lanckoronianki: „Chciałam, żeby kobiety wyszły z domów, spotykały się i wymyśliłam Lanckoronianki. Najpierw były to spotkania nieformalne, a od $2015 \mathrm{r}$. zarejestrowaliśmy stowarzyszenie w KRS". Jej pomysłem jest inscenizacja bożonarodzeniowej szopki na rynku oraz orszak Trzech Króli wjeżdżający na koniach i wspólne kolędowanie w to święto na rynku. Stwierdza, że nowe wydarzenia niewątpliwie bardziej przyciągają turystów niż miejscowych, ale „powoli, bardzo powoli to się zmienia" (2019, ok. 40 lat).

Przestrzeń publicznązdominowały działania zorientowane na ożywienie i promocję miejscowości i tę rolę spełniają, o czym świadczą m.in. wzmożony ruch turystyczny, wzrastające zainteresowanie zakupem domów, działek budowlanych. Na płaszczyźnie marketingu sprawdza się formuła rozrywkowo-kulinarna, bardziej ukierunkowana na zewnętrznych odbiorców niż na miejscowych. Widać to w lokalnej percepcji tego typu imprez - część mieszkańców włącza się w ich organizację i aktywnie w nich uczestniczy, niektórzy przy tej okazji czerpią korzyści (reklama, usługi, handel), jeszcze inni zdecydowanie je odrzucają. Przeczy to diagnozie Waldemara Kuligowskiego analizującego fenomen małomiasteczkowych wydarzeń o charakterze festiwalowym, gdy stwierdza, że są one: 
wyraźnie socjocentryczne. Bierze się w nich udział, aby spotkać sąsiadów, znajomych, kolegów. [...] Liczy się możliwość wspólnego spotkania, biesiadowania, spędzenia wolnego czasu. Estradowa gwiazda czy stragany z lokalnymi wyrobami funkcjonują jako dogodny pretekst do podtrzymywania i nawiązywania więzi. Dokonuje się tym samym afirmacji - choćby jedynie czasowej - własnej grupy i własnego miejsca. [...] Kultura wychodząca na ulice i place pociąga za sobą wychodzących na ulice i place ludzi. Przy czym nie tworzą oni wspólnoty protestu, ale wspólnotę zabawy ${ }^{2 x}$.

W Lanckoronie nie potwierdza się teza o wspólnotowej funkcji wydarzeń festiwalowych, wręcz odwrotnie - wyraźnie uwydatniają one podziały istniejące w lokalnym społeczno-kulturowym świecie.

Wracam jeszcze do refleksji nad statusem miejscowych i przybyszy, w tym moim oraz osobom mnie podobnym. Trudno jednoznacznie orzec, czy radna jest „prawdziwą” lanckoronianką czy przybyszem. Czuje się związana zarówno z Sułkowicami, jak i z Lanckoroną. Podobnie i ja, krakowianka pomieszkująca w Lanckoronie, czy B. Frymorgen, który tak kończy swój album: „Od lat wpatruję się w te mury jak w stare mapy. Gdzieś w szczelinach szukam własnej historii. Bo przecież to jest również moja Lanckorona. Mój Zamek, Ruiny"22. Mnożę pytania - jak porównać rodowitego lanckoronianina i nowego właściciela dawno nieczynnego pensjonatu zamienionego przezeń na rodzinny dom? Jak zmierzyć i jak nazwać ich i moje poczucie osadzenia w Lanckoronie? Mnie też przeszkadza weekendowy nalot turystów, ale przecież sama go pomnażam, jak i ci, którzy tak jak ja do Lanckorony wracają, odwiedzają krewnych nadal tu mieszkających, bliskich na cmentarzu. Uczestniczą w familijnych spotkaniach, weselach, pogrzebach. Ale zaglądają też do Arki (to nazwa jednej z nowszych kawiarni) na mocne cappuccino, do Cafe Pensjonatu poczytać najnowszy numer „Kuriera Lanckorońskiego" wydawanego przez Towarzystwo Przyjaciół Lanckorony. Okazjonalnie posłuchają jazzu, gitary klasycznej, arii operowej w ramach organizowanych w Lanckoronie festiwali. Są ciekawi zmian w otoczeniu, jedne akceptują, inne krytykują, włączają się w lokalne działania albo i nie. Tak jak i inni lanckoronianie identyfikują się z lokalną przestrzenią i jak oni podmiotowo jej doświadczają.

Współczesna Lanckorona jawi się jako miejsce ścierania się przychodzących z zewnątrz nowoczesnych elementów z miejscowymi tradycjami.

2I W. Kuligowski, Festiwalizacja prowincji. Mate miasta wobec wielkich trendów, [w:] Mate miasta w czasach ptynnejponowoczesności, red. E. Nowina-Sroczyńska, T. Siemiński, Pruszcz Gdański-Bytów 2014, s. 47.

22 B. Frymorgen, dz. cyt., s. 8I. 
Jest to nasilający się proces, prowadzący do detradycjonalizacji lokalnego stylu życia na rzecz idei i wartości upowszechnianych w globalnym obiegu ${ }^{23}$, a lanckoronianie - autochtoni, rezydenci, nowi osiedleńcy - różnie w nim się odnajdują. Różnie też określają siebie w posttradycyjnej czasoprzestrzeni, dążąc do uczynienia z niej swojego świata.

\section{Bibliografia}

\section{Literatura}

Autoetnografia - technika, metoda, nowy paradygmat? O metodologicznym statusie autoetnografii, red. A. Kacperczyk, „Przegląd Socjologii Jakościowej" 2014 , nr 3.

Buczyńska-Garewicz H., Miejsca, strony, okolice. Przyczynek do fenomenologii przestrzeni, Kraków 2006.

Bujak J., Jak się zaktada muzeum, „Przekrój” 1967, nr II83.

Bujak J., Problem szkolenia studentów etnografii w zakresie muzealnictwa etnograficznego, „Rocznik Muzeum Etnograficznego w Krakowie” 1968, R. 3.

Buliński T., Informator, rozmówca, wspólnik. Obrazy relacji Antropologa z Innym, „Zeszyty Naukowe Uniwersytetu Jagiellońskiego. Prace Etnograficzne” 2019, z. I.

Frymorgen B., Lanckorona, Londyn 2015.

Geertz C., Zdobywając doświadczenia, autoryzując siebie, [w:] Antropologia doświadczenia. $Z$ epilogiem Clifforda Geertza, red. V.T. Turner, E.M. Bruner, Kraków 201 I.

Godula-Węcławowicz R., Miasteczko Lanckorona. Mityzacja przesztości, [w:] Evropské mèsto. Identita, symbol, mýtus, red. B. Soukupová, H. Novotná, Z. Jurková i A. Stawarz, Bratysława 2010.

Kantor R., Muzeum w Lanckoronie w świadomości i ocenie mieszkańców, „Zeszyty Naukowe Uniwersytetu Jagiellońskiego. Prace Etnograficzne” I98I, z. I4.

Kuligowski W., Festiwalizacja prowincji. Mate miasta wobec wielkich trendów, [w:] Mate miasta w czasach ptynnejponowoczesności, red. E. Nowina-Sroczyńska, T. Siemiński, Pruszcz Gdański-Bytów 2014.

Lenczowski F., $Z$ dziejów Lanckorony, „Studia Historyczne” 1973, R. I6 (4).

Perzanowski Z., Lanckorona. Powstanie miasta i dzieje jego rozwoju do końca XVI wieku, [w:] Ojczyzna blizsza i dalsza. Studia historyczne ofiarowane Feliksowi Kirykowi w sześćdziesiąta rocznicę urodzin, red. J. Chrobaczyński, A. Jureczko, M. Śliwa, Kraków 1993.

Sypowski F., Miasta Lanckorony świadki przesztości. Z publicystyki i historii dawnej kultury polskiejkart kilka, Wieliczka 1938.

Warczok T., Globalizacja i konsumeryzm. O konsumpcji jako strategii zaradczej wobec traumatogennych zjawisk globalizacji, [w:] Konsumpcja - istotny wymiar globalizacji kulturowej, red. A. Jawłowska, M. Kempny, Warszawa 2005.

Wiśniak K., Powietrznicy w Lanckoronie. Historia letniska, Kraków 2008.

Wnuk-Lipiński E., Oblicza globalizacji-konceptualizacja pojęcia, [w:] Globalizacja. I co dalej?, red. S. Amsterdamski, Warszawa 2004.

23 E. Wnuk-Lipiński, Oblicza globalizacji - konceptualizacja pojęcia, [w:] Globalizacja. I co dalej?, red. S. Amsterdamski, Warszawa 2004, s. 27. 


\section{Strony internetowe}

Podróże Starszego Pana, http://podrozestarszegopana.radom.pl/lanckorona/index.html

Tripadvisor, https://pl.tripadvisor.com/ShowUserReviews-g3420966-d13947715 -r569952450-Market_Square_in_Lanckorona-Lanckorona_Lesser_Poland_Province_Southern_Poland.html

Urząd Gminy Lanckorona, https://bip.malopolska.pl/uglanckorona,m,233013,dokumenty.html

Streszczenie: Źródłem rozważań są etnograficzne obserwacje, które poczyniłam w Lanckoronie, jednej z najbardziej rozpoznawalnych i popularnych miejscowości Małopolski. Do ich tworzenia i interpretacji wybrałam autoetnograficzną perspektywę jako najbardziej adekwatną do mojej sytuacji badawczej - etnologa mającego osobiste związki z analizowaną rzeczywistością społeczno-kulturową. Lanckorona jest przykładem ścierania się przychodzących z zewnątrz elementów nowoczesnych z tradycyjnymi, których wypadkową jest odmienne doświadczanie, przeżywanie i wartościowanie przestrzeni lokalnej. Prowadzi to do kulturowych napięć ujawniających się w relacjach: autochtoni - przybysze - turyści. W tym kontekście rozważam swój status w Lanckoronie.

Słowa klucze: Lanckorona, autoetnografia, doświadczenie przestrzeni, tożsamość lokalna

Summary: The source of my considerations are the ethnographic observations I made in Lanckorona, one of the most recognizable and popular localities in Małopolska. For their creation and interpretation, I chose the autoethnographic perspective as the most appropriate to my research situation - an ethnologist having personal connections with the analyzed socio-cultural reality. Lanckorona is an example of a clash of modern elements coming from the outside with traditional ones, the result of which is a different experience, feeling and evaluation of local space. This leads to tensions that appeared in the relations: autochthons - strangers - tourists. In this context, I consider my status in Lanckorona.

Keywords: Lanckorona, autoethnography, experience of space, local identity 